\title{
Decomposition of food waste using bulking agent and bio-drying technology
}

\author{
Wiharyanto Oktiawan ${ }^{1}$, Mochtar Hadiwidodo ${ }^{1}$, Ika Bagus Priyambada ${ }^{1}$, Purwono Purwono ${ }^{2 *}$ \\ ${ }^{1}$ Department of Environmental Engineering, Faculty of Engineering, Diponegoro University, Semarang - Indonesia \\ ${ }^{2}$ The State Islamic Institute of Surakarta-Indonesia
}

\begin{abstract}
Technology to process food waste should be easy maintenance, fast, economical, affordable, environmentally friendly, and socially acceptable. Processing food waste according to the principle is biological decomposition. Biological processes usually take quite a long time (30 days). This study aims to accelerate the process of decomposition of food waste and produce a quality fertilizer products. Bulking agent (biofilm), bio activator (microorganism from cassava), and bio-drying technology are used to accelerate the decomposition process. The ratio of food waste and bulking agent is 7:3 (v/v). Mature product serves as a bulking agent and additive microorganisms. Additive microorganisms are also done by adding microorganism derived from cassava with a ratio of $10 \mathrm{ml} / 500 \mathrm{~g}(\mathrm{M} 1) ; 20 \mathrm{ml} / 500 \mathrm{~g}$ (M2); and 10ml/500 $\mathrm{g}$ of food waste (M3). The results showed the temperature of the food waste reached $50 \square$ at first. The addition of bulking agent and Additive microorganisms causes the thermophilic phase to occur early. This shows the thermophilic phase being achieved in a short period. Based on testing of compost maturity parameters, food waste has matured within 3 days. The C-Organic Concentration was $27.57 \%$, N-total $1.98 \%, \mathrm{C} / \mathrm{N}$ ratio of 13.92 , P-Total $0.23 \%$ and K-total $0.83 \%$. In conclusion of this study, mature compost can be used as bulking agent with mature compost ratio and 7: $3(\mathrm{v} / \mathrm{v})$ bulking agent. Processing food waste is quite effective using a combination of bulking agent (mature compost), additive microorganisms and bio-drying technology.
\end{abstract}

Keywords: food waste, decomposition, bio-drying, microorganisms

\section{Introduction}

Food waste can be meat, fish, cooked food scraps, moldy bread, bone remnants, cakes, expired meals, dairy products, fruits and vegetables [1]. When the waste is fed into the trash, it will occur decay and produce a foul odor which in turn will bring flies. The amount of food waste generated from household activities is relatively high at $>$ $60 \%$ and other amounts of recyclable food waste, such as plastics, paper, glass, and metal. Food waste cannot be recycled or sorted because it contains very high water content up to $74.5 \%$. This waste has the potential to produce pollutants in the form of leachate, odor and air pollution [2]. Food waste treatment technology should be economical, affordable, environmentally friendly, and socially acceptable [3], technology should be cheap, energy efficient, easy maintenance, effective, portable, and stable. Processing food waste according to the principle is biological decomposition. Biological processes usually take quite a long time (30 days).

The most interesting food waste management technologies in recent years is bio-drying (Biological Drying) where food waste will undergo bioconversion
[4]. Bio-drying integrates mechanical processes (air circulation and food waste enumeration) and bioconversion (biological drying). In practice, the biodrying reactor processes food waste with the high moisture content that has been chopped and produces biodried food waste output. Drying food waste using heat comes from a combination of decomposition of organic compounds and excess air [5]. The most obvious advantages of the bio-drying process are accelerating stabilization, decreasing water content, volume, odor, and weight of food waste, which in turn can improve handling, transport and minimize food waste disposal from households. The use of bio-drying produces low specific carbon dioxide $\left(\mathrm{CO}_{2}\right)$ emission, thus minimizing the effects of climate change due to waste management [5].

The process of decomposition of food waste can be accelerated by regulating particle size [6]. Distribution and particle size of food waste affects the growth area of decomposing microorganisms and maintains sufficient porosity for the aeration process. The greater the size of

* Corresponding author: badruszaman2@gmail.com 
the food waste particles, the microorganisms cannot reach the middle part of food waste which affects the slow decomposition. Food waste needs to be enumerated first so that the particle size is smaller and homogeneous. A portable garbage collection machine (easy to carry anywhere) will make it easier for someone to process food waste on a household scale.

Microorganisms have important role in the process decomposing of food waste. Various types of microorganisms jointly decompose food waste [7]. Microorganisms develop according to the temperature of the composting process, which indicates various kinds of decomposition processes. At food, processing site needs to add microorganism from outside. Based on previous research shows that the use of mature and stable compost can used as a source of microorganisms to accelerate the decomposition process. The raw material composition is $40 \%$ manure and $60 \%$ leaf waste. In this case, mature compost also functions as a bulking agent to facilitate the dispersion or decay of organic waste in the composting process because of its porous nature so that the transfer of oxygen from the air into the soil can run smoothly [8].

Based on this background, this research aims to accelerate the process of decomposition of food waste and produce quality fertilizer products. Bulking agent, microorganism (microorganism from cassava), and bio-drying technology are used to accelerate the decomposition process. Food waste will be the main food endowment product of compost. Quality compost fertilizer is seen from the level of stability, maturity, and level of toxicity and the speed of degradation of food waste.

\section{Method}

Bio-drying reactor made using plastic material tubular with height $30 \mathrm{~cm}$ and diameter of $23 \mathrm{~cm}$. The reactor is equipped with a blower $(5 \mathrm{~V}, \mathrm{DC})$ mounted on the side of the reactor and connected with a 2.5 -inch diameter pipe. At the bottom, there is a small pipe as a leachate outlet. The reactor lid is given a $0.5 \mathrm{~cm}$ diameter hole as a place of air circulation. The blower is powered by an electric current equipped with a power supply. Food waste is mashed, then put into a reactor with a ratio of the amount of food waste and 7: $3(\mathrm{v} / \mathrm{v})$ bulking agent. Furthermore, the mixture is added as 1 gram of dolomite lime. To determine the effect of microorganisms on the composting process, the addition of local microorganisms as much as $10 \mathrm{ml}$ per 500 grams of waste (M1), $20 \mathrm{ml}$ per 500 grams of waste (M2) and $30 \mathrm{ml}$ per 500 grams of waste (M3). Local microorganisms are derived from the fermentation of cassava tape. Each day, the mixture is stirred manually and measured $\mathrm{pH}$ and temperature. Sampling was done at the beginning and end of composting to be tested Duplo on levels of C, N, P, and $\mathrm{K}$. The temperature measurements using a waterproof stainless steel temperature sensor with a precision of 0.01 ${ }^{\circ} \mathrm{C}$. Recorded data will be stored in SD Card in .xlsx format. Temperature range between $-50{ }^{\circ} \mathrm{C}$ to $200{ }^{\circ} \mathrm{C}$. The probe sensor is placed at the center of the reactor. Measurement methods $\mathrm{C}, \mathrm{N}, \mathrm{P}$, and $\mathrm{K}$ in accordance with SNI. Compost raw material consists of food waste, mature compost and local microorganisms derived from cassava fermentation tape. The dolomite lime used has a $\mathrm{pH}$ of 7.8. Characteristics of compost raw materials are shown in Table 1.

Table 1. Concentration of macro elements of compost raw materials

\begin{tabular}{|c|c|c|c|}
\hline Parameter & $\begin{array}{c}\text { Food waste } \\
(\mathbf{\%})\end{array}$ & $\begin{array}{c}\text { Compost } \\
(\mathbf{\%})\end{array}$ & $\begin{array}{c}\text { Microorganism } \\
\text { Local (\%) }\end{array}$ \\
\hline C-Organic & 34,90 & 12,80 & 90,24 \\
\hline N-Total & 2,40 & 1,17 & 8,99 \\
\hline C/N & 14,50 & 10,91 & 11,15 \\
\hline P-Total & 0,02 & 0,03 & 0,06 \\
\hline K-Total & 1,04 & 0,81 & 0,16 \\
\hline
\end{tabular}

\section{Results and discussion}

\subsection{Temperature}

The composting process and microbial activities produce different temperature patterns. The temperature measurement results during composting are shown in Fig. 1 (a). The optimal temperature in the composting process is $30-50 \square$. Based on these data it is seen that M1 reactor (local microorganisms as much as $20 \mathrm{ml} / 500$ gram of garbage) can produce high enough temperature $(480 \mathrm{C})$ on day 1 and increase until $50 \mathrm{oC}$ on the second day. On the same day, M2 and M3 produce a maximum temperature of $39 \mathrm{oC}$ and $49 \mathrm{oC}$. The reactor control temperature reached $50 \mathrm{oC}$ on day 1 but decreased to $31^{\circ} \mathrm{C}$ on the second day. The addition of mature compost (bulking agent) at the beginning of composting successfully increased the temperature of the compost to the thermophilic, where the addition of bulking agent provides advantages for microorganism activity and increases the degradation of organic material [9]. In this study, the ratio of the amount of food waste and compost mature (bulking agent) $7: 3(\mathrm{v} / \mathrm{v})$. This temperature rise is also supported by bio-drying systems that accelerate the decomposition process aerobically. The increase in temperature is a result of the decomposition of organic compounds such as amino acids, glucose, organic acids etc [10]. The compounds are easily metabolized and mineralized by heterotrophic bacteria. Metabolic activity and high exothermic process that increases the temperature of solid waste at the Bio-drying process. For example catabolism reactions in the bacterial cells. decomposition of glucose $\left(\mathrm{C}_{\mathrm{n}} \mathrm{H}_{2 \mathrm{n}} \mathrm{O}_{\mathrm{n}}\right)$ on aerobic conditions release heat of $896 \mathrm{~kJ}$ as the following reaction:

$\mathrm{C}_{6} \mathrm{H}_{12} \mathrm{O}_{6}+6 \mathrm{O}_{2} \rightarrow 6 \mathrm{CO}_{2}+6 \mathrm{H}_{2} \mathrm{O} \Delta \mathrm{G}^{\mathrm{o}}=-2,872 \mathrm{~kJ}$ (heat) 


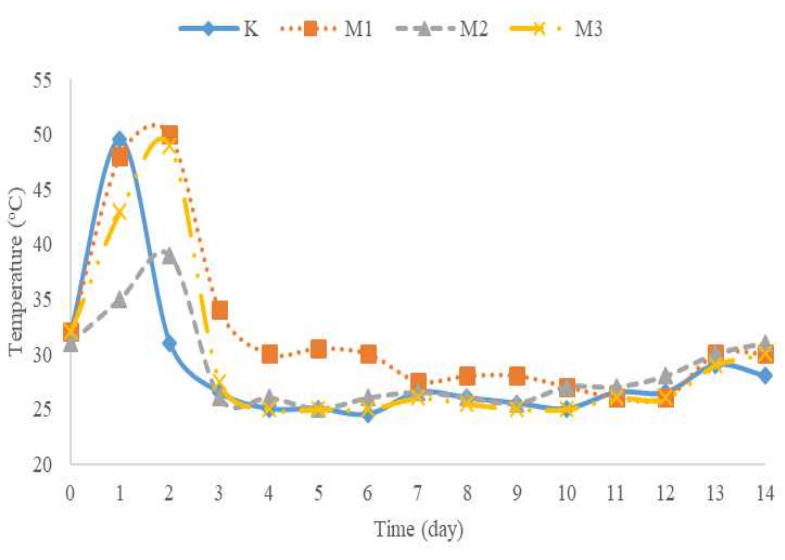

(a)

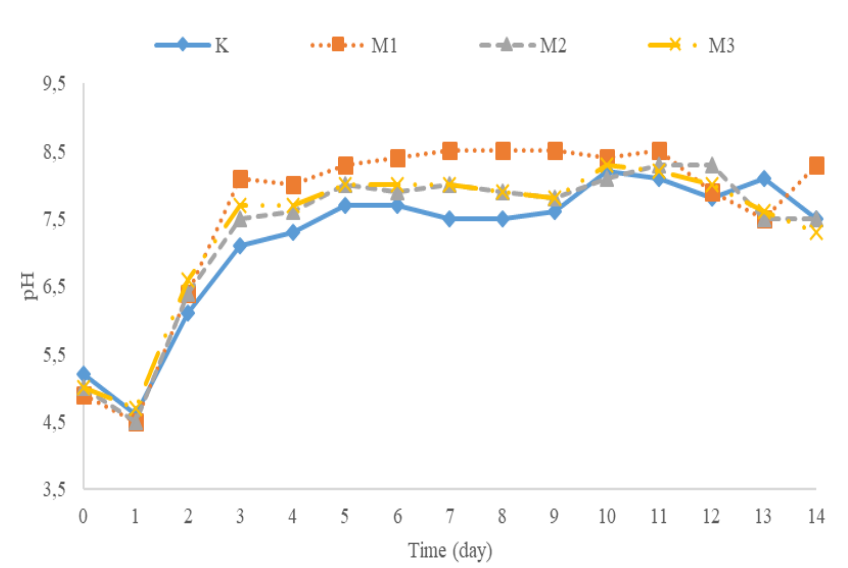

(b)

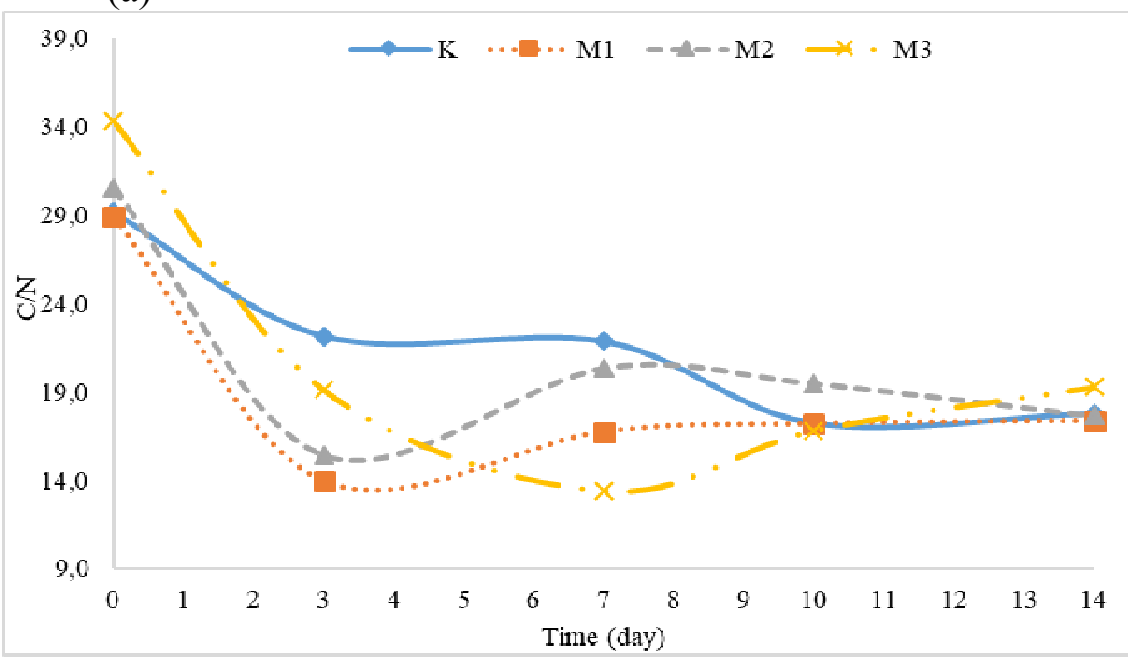

(c)

Fig. 1. Temperature graph (a), $\mathrm{pH}$ graph (b), $\mathrm{C} / \mathrm{N}$ graph (c) on various composting times. $\mathrm{M} 1$ is a mixture of $10 \mathrm{ml}$ of local microorganisms and 500 grams of waste, M2 is a mixture of $20 \mathrm{ml}$ of local microorganisms and 500 grams of waste, and M3 is a mixture of $30 \mathrm{ml}$ of local microorganisms and 500 grams of waste. While $\mathrm{K}$ is a control consisting of a mixture of food waste as much as 500 grams.

\subsection{Pondus Hidrogeny $(\mathrm{pH})$}

$\mathrm{pH}$ parameter needs to be measured with the purpose of supporting good microbial activity during composting. The $\mathrm{pH}$ measurement results during composting are shown in Fig. 1 (b). According to [11], $\mathrm{pH}$ changes show the activity of microorganisms in degrading organic matter. On day 2 , food waste decreases due to the formation of simple organic acids. The next day $\mathrm{pH}$ increases because microorganisms convert inorganic nitrogen to ammonium which is alkaline. The $\mathrm{pH}$ value is also influenced by the addition of local microorganisms. This is in accordance with the study of Nugroho et al. (2010) which states that composting with the addition of inoculant causes the $\mathrm{pH}$ to be higher after the second day. This $\mathrm{pH}$ value also illustrates that at the beginning of composting organic acid production is more generated by microorganism so that last longer, $\mathrm{pH}$ value on compost with inoculant is higher than without inoculant until end of the experiment. The resulting $\mathrm{pH}$ value corresponds to the optimum $\mathrm{pH}$ between 5.5 and 8.0 [12].

\section{3. $\mathrm{C} / \mathrm{N}$ ratio}

One criteria on evaluated in the literature to characterize quality is $\mathrm{C} / \mathrm{N}$ ratio. The bio-drying process is influenced by the $\mathrm{C} / \mathrm{N}$ ratio, which has an important role in the continuity of this process. The $\mathrm{C} / \mathrm{N}$ ratio describes microorganisms in compost oxidizing carbon as an energy source and consuming nitrogen for protein synthesis [7]. The measurement result of $\mathrm{C} / \mathrm{N}$ ratio during composting is shown in Fig. 1c. Based on the results of the study, the composition of the initial food waste ranged from 28.9 to 34.4. Based on the $\mathrm{C} / \mathrm{N}$ ratio, this process has reached its optimum in the range of 25-35. Because it is considered that the microorganisms require 28.9 to 34.4 parts of $\mathrm{C}$ per unit of $\mathrm{N}$ [13]. In other words, the composition of a mixture of food waste with a comparison of the amount of food waste and 7: $3(\mathrm{v} / \mathrm{v})$ bulking agent is suitable for the composting process. According to [14]. $\mathrm{C} / \mathrm{N}$ ratio of mature compost ratio should be $<20$ and better $<10$. On the third day, the 
variation of $\mathrm{M} 1$ produces a $\mathrm{C} / \mathrm{N}$ ratio of 13.92 which indicates that the compost is ripe. This value is the lowest value compared to $\mathrm{M} 2(\mathrm{C} / \mathrm{N}=15.4)$ and $\mathrm{M} 3(\mathrm{C} / \mathrm{N}=$ 19.1). While the control reactor produces a $\mathrm{C} / \mathrm{N}$ ratio of 22.1. Mature compost in the reactor control was reached on day 10 with a $\mathrm{C} / \mathrm{N}$ ratio of 17.2 . Overall quality of $\mathrm{M} 1$ compost on the third day was $\mathrm{C} / \mathrm{N}$ ratio of 13.92; Organic C-concentration of $27.57 \%$; N-total $1.98 \%$; P-Total is $0.23 \%$, and K-total is $0.83 \%$. Based on the results of this study it can be concluded that the addition of local microorganisms as much as $10 \mathrm{ml} / 500$ grams (M1) mixture of food waste can accelerate the process of compost maturity.

\section{Conclusion}

Based on testing of compost maturity parameters, food waste has matured within 3 days. The C-Organic Concentration was $27.57 \%$, N-total $1.98 \%, \mathrm{C} / \mathrm{N}$ ratio of 13.92 , P-Total $0.23 \%$ and K-total $0.83 \%$. In conclusion of this study, mature compost can be used as a bulking agent with mature compost ratio and 7: $3(\mathrm{v} / \mathrm{v})$ bulking agent. The addition of local microorganisms as much as $10 \mathrm{ml} /$ 500 gram (M1) mixture of food waste can accelerate the process of compost maturity. Processing food waste is quite effective using a combination of bulking agent (mature compost), additive microorganisms and biodrying technology.

\section{The acknowledgments}

Thank you to DRPM DIKTI for funding this research through PTUPT grant financing year 2018

\section{References}

1. Callaghan, T., "How to compost ALL food waste," http://hotbincompostingblog.com/compost-all-foodwaste/, 2012.

2. He, P J, Shao L M, Qu X, Li G J, Lee D J. Effects of feed solutions on refuse hydrolysis and land fi 11 leachate characteristics. Chemosphere, 59(6): 837844. (2005).

3. Massoud, M.A., Tarhini, A., Nasr, J.A. Decentralized approaches to wastewater treatment and management: applicability in developing countries. J. Environ. Manage. 90 (1), 652-659. (2009).

4. Rada, E. C., Ragazzi, M., V. Panaitescu. MSW biodrying: an alternative way for energy recovery optimization and landfilling minimization, U.P.B. Sci. Bull., Series D, Vol. 71, Iss. 4, (2009)

5. Velis, C.A., P.J. Longhurst, G.H. Drew, R. Smith, S.J.T. Pollard. Biodrying for mechanical-biological treatment of wastes: A review of process science and engineering. UK: Bioresource Technology 100 (2009) 2747-2761(2009).

6. Bernal, M.P., Paredes, C., Sánchez-Monedero, M.A., Cegarra, J. Maturity and stability parameters of composts prepared with a wide range of organic wastes. Bioresour. Technol. 63, 91-99. (1998).

7. Ryckeboer, J., Mergaert, J., Vaes, K., Klammer, S., De Clercq, D., Coosemans, J., Insam, H., Swings, J. A survey of bacteria and fungi occurring during composting and self-heating processes. Ann. Microbiol. 53, 349-410 (2003).

8. BRDP, "Mengubah Sampah Organik Perkotaan Menjadi Uang”, (2005). http://www.bdrp.or.id/kegiatan/artikel/kompossamp ah2.html, diakses 25 tanggal Mei 2018.

9. Yang, F., Li, G.X., Yang, Q.Y., Luo, W.H. Effect of Bulking Agenta on Maturity and Gaseous Emissions During Kitchen Waste Composting. Chemosphere 93 (7), 1393-1399 (2013).

10. de Bertoldi, M., Vallini, G., Pera, A. The biology of composting: a review. Waste Manage. Res. 1, 157176 (1983).

11. Ismayana. Faktor Rasio $C / N$ awal dan laju Aerasi pada Proses Composting Bagasse dan Blotong. Teknik industri Pertanian. (2012).

12. Miller, F.C., Composting as a process based on the control of ecologically selective factors. In: Metting, F.B., Jr. (Ed.), Soil Microbial Ecology, Applications in Agricultural and Environmental Management. Marcel Dekker, Inc., New York, pp. 515-544 (1992).

13. Bishop, P.L., Godfrey, C., Nitrogen transformation during sewage composting. Biocycle 24, 34-39 (1983).

14. Mathur, S.P., Owen, G., Dinel, H., Schnitzer, M., Determination of compost biomaturity. Literature review. Biol. Agric. Hortic. 10, 65-85 (1993). 